\section{Spread of African Pasture Grasses to the American Tropics ${ }^{1}$}

\section{JAMES J. PARSONS}

\author{
Professor of Geography, Department of Geography, \\ University of California, Berkeley.
}

\section{Highlight}

Most of the economically important pasture grasses of the tropics have originated in Africa. Introduced into the New World, they have often become naturalized, spreading rapidly and widely. Six species have been principally involved in this massive ecologic invasion. With the aid of man the face of much of the continent is gradually being changed from forest to productive grassland.

The once limitless forests of humid tropical America are rapidly being converted to grasslands. Areas newly cleared of selva or montaña are cropped for a few years, then planted to perennial African grasses to form "artificial" pastures. These generally have been aggressively colonizing species, readily disseminated either by seed or cutting, and they have become widely naturalized. Agriculture is thus but a temporary stage in the process by which forest is being converted to potreros, especially where grazing pressure, set fires, and the purposeful cutting or uprooting of aggressive woody species promote the dominance of grasses over secondgrowth vegetation (rastrojo). There is a surge and ebb to the forestgrassland boundaries thus created, but the relentless sweep of the colonos axe is producing an everwidening sea of grass. Where once stood great tracts of lowland forest -along the Pan American Highway in Mexico and Central America, on

\footnotetext{
${ }^{1}$ This research has been supported by the Geography Branch, Office of Naval Research, and the Center for Latin American Studies, University of California, Berkeley. This is a revision and extension of an earlier paper, "The Africanization of the New World Tropical Grasslands," which appeared in Tübingen Geographische Studien, 34:141-153 (1970). Received February 6,1971 .
}

the north coast of Colombia, on the Andean spurs of castern Venezuela, in the interior of Brazil, on the islands of the Greater Antilles-today one sees pasture lands stretching to the horizon, interrupted only by scattered palms, remnant woodlots, or linear rows of trees planted originally as live fences. The tropical forest of Latin America, so long considered inviolate, is under serious and sustained attack on countless fronts and it must now be considered an important question whether it will long endure (Sternberg, 1968).

Tropical Africa-especially Angola, Rhodesia, and the Transvaal -has been an independent center of development for a number of sown forage grasses, including virtually all of the important ones that may be considered truly tropical (Hartley and Williams, 1956). Most of thesc are said to have evolved from woodland or forest margin habitats (Cooper, 1965). Although originally they appear to have had quite restricted distributions in Africa, they are today found over wide areas of 'derived' savanna surface that once supported trees. Introduced into America, these grasses have proven to be explosively aggressive, invading and holding vast areas wherever they have received minimal support by man. For most of them numerous subspecies or ecotypes have been recognized, but little is known regarding their differing ecologic adaptations and the mechanisms for them (Torres, 1954). The role of genetic variability, including polyploidy, in the evolution of these invasive species remains to be investigated. It is noteworthy that all appear to have the ability to respond to higher soil nutrient levels than those encountered in the regions from which they came. In- variably they are more palatable to livestock than the nativc Amcrican species, and more productive. Such adaptability to grazing clearly must be related to their simultaneous evolutionary development with grazing animals in their areas of origin during the late Pliocene and Pleistocene.

There are no data on how much of Tropical America today supports a grass cover. It is a patchwork quilt. Excluding the Amazon basin, it must approach 40 per cent. What part of this surface supports naturalized African species is not known. Although the vegetation maps may not show it, grass, whether volunteer, planted, or simply encouraged by man, is the most widespread of all cover types over much of the continent. Most pastures and extensive tracts of so-called savanna are, in fact, a mixture of native and introduced grasses.

A half dozen species of Gramineae have been principally involved to date in this African invasion: Guinea grass (Panicum maximum Jacq.), Pará grass (Brachiaria mutica (Forsk.) Stapf), molasses grass (Melinis minutiflora Beauv.), jaraguá (Hyparrhenia rufa (Nees) Stapf), Kikuyu grass (Pennisetum clandestinum Hochst.), and, most recently, Pangola grass (Digitaria decumbens Stent). The first two have been longest in the Americas and are probably the best known and most valued, although some of the later arrivals have been more aggressive colonizers.

\section{Guinea Grass}

Guinea grass (Panicum maximum), a tall growing clump-former that may be propagated either by seeds or cutting, is undoubtedly the most widespread. It is also known as hierba de India (Colombia), privilegio or zacatón (Mexico), and capim colonião (Brazil). Its establishment in the West Indies apparently dates from the seventeenth century. In 1684 Hans Sloane, founder of the British Museum, collected and described a "Scotch grass" in Barbados, and later in 


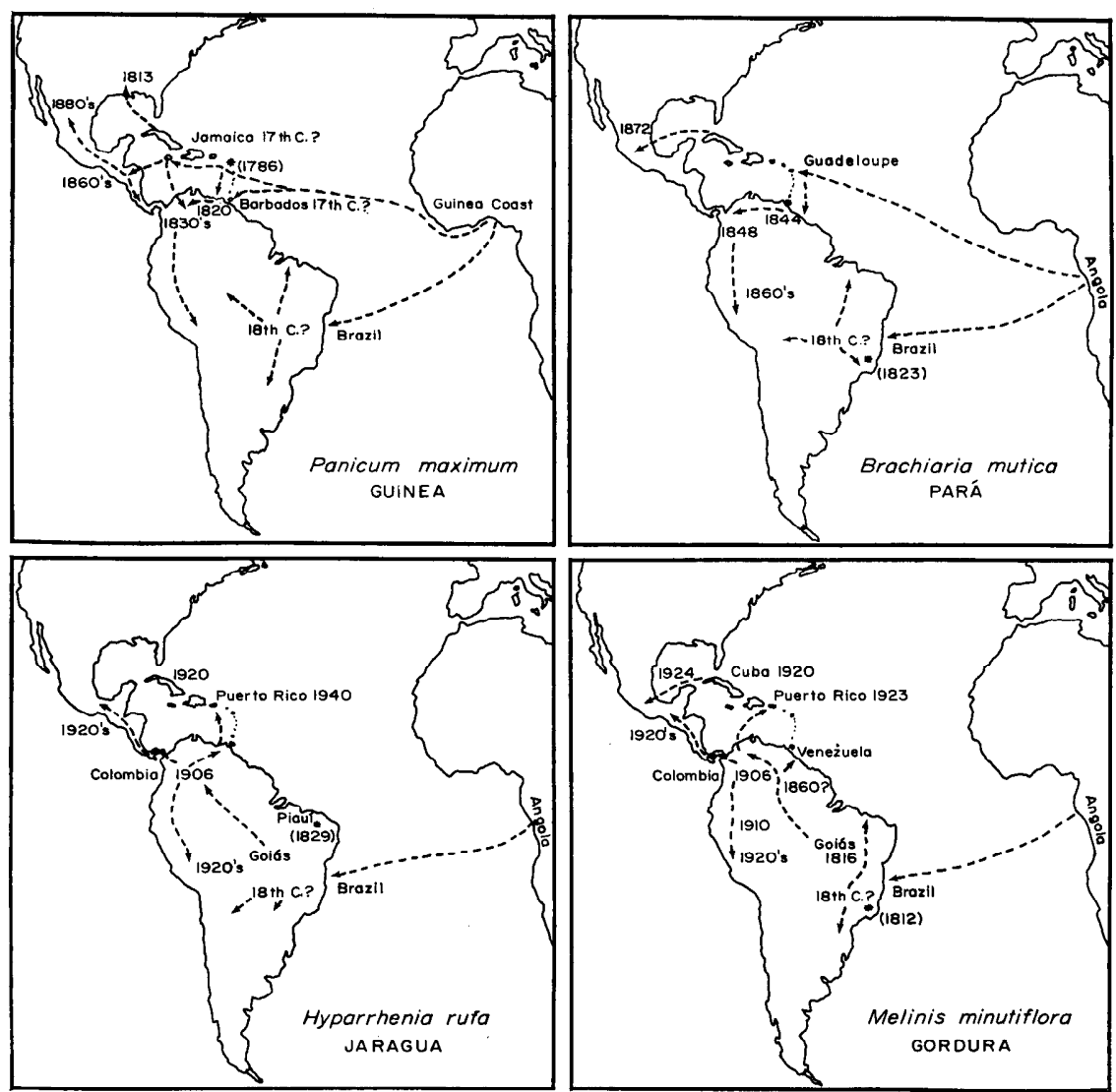

Fig. 1. The spread of some African pasture grasses into the Ncw World tropics. * $(1823)=$ place of collection and date of first scientific description of species.

Jamaica (Sloane, 1707, p. 106). He labeled it "gramen paniceum maximum or paniceum vulgare." $\mathrm{He}$ described it as 4-5 feet tall with thick nodes at six-inch intervals on the stalk, being:

"Planted in moist ground all over the island for provision for cattle, but grows wild ... in the north side [of Jamaica] and in part of Barbadoes called Scotland, whence the name. After its being found very useful in Barbadoes, and had been there planted for some time, it was brought hither [Jamaica] and is now all over the island in the moister land by river sides, planted after the manner of sugar canes."

Such an early English introduction would fit into a pattern of fairly widespread introductions of economic plants to the West Indies from West Africa, for many slave ships made Barbados their first and often only port of call. Alternately the seed might have arrived from Brazil, with which Barbados had fairly close associations at the time. But to be sure that Sloane's grass was indeed Panicum maximum we need to examine his collections in London.

Bryan Edwards, the historian of Jamaica, writing prior to 1794 , was enormously impressed with the rapid spread of "Guinea grass," but he, like several other observers, attributed its presence in the West Indies to a casual introduction from Africa to Jamaica in 1740 or 1741 by the captain of a slave ship who had intended it for use as bird seed. Multiple introductions seem quite likely. Commenting on the revolutionary impact of the grass, he observed (Edwards, 1801, p. 253):

“. . . Most of the grazing and breeding farms, or pens, throughout the island [of Jamaica] were originally created and are still supported by this invaluable herbage. ... Perhaps the settle- ment of most of the north-side parishes is wholly owing to the introduction of this excellent grass, which happened by accident about 50 years ago ...."

Its spread throughout the West Indies was apparently rapid. The first scientific description of the grass, in 1786, was from a specimen collected in Guadeloupe, where it was said to have become naturalized ("In insula Guadeloupe sponte crescit"). By the end of the century it was described as being "extensively cultivated" in $\Lambda$ ntigua, where it had been introduced from Jamaica. As early as 1813 it had reached Mississippi, approximately the northern limit of its range in the New World (Weintraub, 1953).

Guinea grass appears to have been introduced to New Granada (Colombia) from Jamaica in 1797 (Restrepo, 1963). Here, too, it is reported to have been looked upon at first as only a curiosity, a source of bird seed. Its large scale cultivation was initiated in the area of Guaduas (Cundinamarca) in the middle Magdalena Valley in the 1830 's where it created a major land-use revolution. One observer called it "a true miracle grass," suggesting that the unknown person responsible for its introduction to that region deserved a statue "as high as New York's Statue of Libcrty, illuminated by night . . . so as to be visible throughout the vast area of the new haciendas of the tierra caliente that it has made productive" (Rivas, 1946). It was also from Jamaica that it reached Central America, apparently sometime around the middle of the 19 th century. Extensive planted pastures of Guinea grass began to appear in Guatemala about this time, reportedly introduced by way of the Soconusco coast of Chiapas (Esponda, 1888). In 1870 "great zacatón potreros full of fat cattle" were described as one of the principal arms of wealth of that republic. In southern Mexico, too, it provided the basis for a greatly expanded livestock industry. A 15-fold increase in land values in the valley 
of the Rio Grijalva in the 1880's was attributed directly to the establishment of the new Guinea grass potreros. The seed was introduced into Costa Rica in 1885 (Pittier, 1957).

The time and manner of the arrival of Guinea grass into Brazil seems to be undocumented. It was undoubtedly early. Indeed numerous Brazilian observers have mistakenly called it native to that country. The late Agnes Chase, authority on all matters pertaining to grasses, suggested that it was probably introduced as bedding on slave ships, establishing itself wherever such vessels unloaded (Chase, 1944). From Brazil it may have gotten to Venezuela, although the more important implantation to that country seems to have come from Colombia in the early years of the nineteenth century.

\section{Pará Grass}

Pará grass (Brachiaria mutica [Panicum purpurascens]), a lower growing stoloniferous grass spreading chiefly by runners, is to the poorly drained bottom lands of the tierra caliente what Guinea grass is to the better drained lower slopes. The name suggests an early connection with the lower Amazon Valley; in the earlier literature it is sometimes referred to as Mauritius grass; in Oaxaca it is known as Egipto, in Colombia as admirable. It has been so long established in Brazil that it has often been listed as a native, but there it is called capim Angola. Like Guinea grass it may have been introduced as bedding in slave ships. It was well established in Brazil at least as early as 1823 , for it was first described taxonomically in that year from a specimen collected at Rio de Janeiro. It was in Guadeloupe, French Wcst Indics, sometime prior to 1844 , when it was taken to Venezuela with some fanfare (Official correspondence... 1849). From there it was carried to the Santa Marta area of Colombia (Ospina Vásquez, 1955). Its adoption was rapid, especially in Antioquia and the middle Magdalena
Valley. It reached the Valle del Cauca in the 1860's. A Colombian observer (Rivas, 1946) at the end of the 19th century wrote of the great prosperity that Pará and Guinea grass had brought to that country:

\section{"In the warm and temperate lands where it was so difficult to maintain clean pasture they are now established easily by means of these two grasses, which destroy all other competing plants."}

Their introduction has been called (Ospina Vásquez, 1955, p. 447) the most important economic event in Colombia between 1820 and the final establishment of coffee as the country's major commercial crop near the end of the century. The introduction of Pará grass into Central America seems to have been relatively late; it reached Mexico from Cuba in 1872. At that time it was already in Guatemala where it was espccially valued for milk production. Today Pará grass is found on moist, poorly drained soils everywhere in the American tropics, including the irrigated pastures of the desert coast of Peru and along the new "penetration roads" reaching down from the Andes into the Amazonian lowlands.

\section{Molasses Grass}

Melinis minutiflora or molasses grass (gordura, melado), so named for its characteristic sweet odor and the gummy exudations that make its hairy leaves sticky, occurs naturally in two disjunct areas of tropical Africa. The western one extends in an arc from central Angola to Cameroun, while another to the east includes the lower slopes and adjacent areas of the Ruwenzori Range and Mount Kenya (Rattray, 1960). The time and manner of its initial introduction into the $\mathrm{New}$ World is unrecorded, but it is clear that molasses grass found here optimal ecologic conditions. The worn and eroded soils of the abandoned coffee lands of the Paraíba Valley, between Rio and São Paulo, are almost taken over by this self- sowing grass, which tends to form a thick and impenetrable mat that snuffs out all competition. It seems to thrive best in disturbed areas and on thin soils, especially in the more temperate "coffee climates." Molasses grass is the basis for much of the modern beef cattle industry of Minas Gerais and Goiás; it covers patches of soil on the steep open sides of the Sugar Loaf and other granitic domes around Guanabara Bay.

The first scientific description of Melinis minutiflora, published in 1812, was from a specimen collected near Rio de Janeiro; it was not identified in its African homeland until nearly half a century later. St. Hilaire observed it in 1816 in Minas Gerais spreading so rapidly northward that he judged it to be an invader (Anon., 1922). Martius, on the other hand, like many other observers, thought it must be indigenous to Brazil. Gardner (1830) observed:

"It is now everywhere so common in this province (Minas) it is difficult to say which of those excellent botanists is right; [but] all of the agriculturalists I have spoken with on the subject agree with St. Hilaire ..."

St. Hilaire had not observed it beyond $17^{\circ} 40^{\prime} \mathrm{S}$, but Gardner met it much further north, especially in the vicinity of houses. He thought that it would soon overrun the mountains on the Goiás-Minas border, its dissemination being greatly aided by cattle.

Despite its early establishment, molasses grass, also known in Latin America as calinguero, seems to have been curiously slow in moving beyond Brazil. It is said to have been introduced from there to Venezuela in 1860, but apparently without major consequence. It was not known in Colombia until 1906 when seeds were inadvertently included in packets of seed of jaraguá, another African invader, that were being sent from Brazil by the Colombian Minister to that country, General Rafael Uribe Uribe (Parsons, 1968, p. 133). The true jaraguá 
took hold slowly and unimpressively in Antioquia, where the seeds were first sown, and since two grasses resulted from the packets sent by General Uribe, the public gave the name yaraguá (jaraguá) to that which prospered better, the unsuspected Melinis. As a result it became known, quite erroneously, as yaraguá or yaraguá Uribe. The confusion in terminology resulting from this circumstance still persists, not only in Colombia but in neighboring Venezuela and in Puerto Rico, to which the species apparently was carried from Colombia.

The spread of molasses grass outward from the point of its initial introduction in Colombia was remarkably rapid. Only three years after it had first been planted in the Amalfi district of Antioquia a hacienda there had demands for morc than 4,000 kilograms of seed coming from all parts of the republic and from Ecuador in response to some articles in a Bogotá newspaper. It was heralded as "the salvation of Antioquia," a province with particularly steep slopes and much thin, eroded soil. At first it was carefully seeded in beds of ashes with the first maize crop in new forest clearings, but it quickly became a volunteer, invading abandoned cafetales, road cuts, railway embankments and even pastures dominated by native grasses. Continuing forest destruction, together with man-set dry-season fires and assiduous roguing of weedy woody growth is encouraging its expansion. A recent study of the Colombian Llanos (Blydenstein, 1967) identifies a "Melinis minutiflora association" on the higher terraces and foothills at the eastern base of the Andes.

In one generation molasses grass has largely taken over the temperate uplands of tropical America. During the 'twenties' it spread southward into Peru and Bolivia and northward through Central America and Mexico. Henri Pittier had observed it in Venezuela in 1913, but restricted only to the immediate vicinity of Caracas. Twenty-three years later, he found it to be "completely naturalized and reproducing spontaneously, as well as being cultivated on a large scale as a forage crop of recognized excellence" (Pittier, 1937). It is first mentioned in Costa Rica in 1908; twenty years later it was described as "completely naturalized" there in some areas. Hitchcock and Chase (1917) do not mention it in their "Grasses of the West Indies." By 1920, however, it was being distributed by a Cuban experiment station, from whence it was introduced into Mexico (Tabasco) four years later (Martinez, 1959). In Mexico, however, it has never become very well established. It was present in Puerto Rico by 1923 , but it was only after a second and well-publicized introduction from Colombia three years later that it began to take hold vigorously (Chardon, 1930). A study of the Puerto Rico grasslands includes a Melinis minutiflora disclimax as one of the principal plant associations in the central highlands (García-Molinari, 1952). In Jamaica's Blue Mountains it has become widespread on "ruinate" lands above 2500 feet elevation. There it is known as Wynne grass and its characteristic spicy fragrance is even mentioned as an attraction in the tourist literature.

\section{Jaraguá}

Jaraguá (Hyparrhenia rufa) is a member of one of the two most common and widespread genera of grasses in tropical and sub-tropical Africa. It is dispersed by seed with uncommon ease and it seems reasonable to assume repeated accidental introductions on slave ships. It was certainly in Brazil early, and like the other grasses previously mentioned has frequently been considered to be part of the native flora. It was first identified taxonomically in 1829 (originally Trachypogon rufus Nees) on the basis of a specimen collected by Martius in Piauí in the northeast of Brazil (Chase and Níles, 1962). Throughout Latin America, it is known by the Tupi name jaraguá ("yaraguá," “faragua") meaning roughly "master of the field." In Brazil, it is also known as capim vermelho, because the tips of the leaves redden conspicuously on maturing.

Remarkably, jaraguá seems not to have spread beyond Brazil to any other part of Latin America prior to General Uribe's introduction of seeds into Colombia in 1906. He himself presumed it to be a native of Goiás, observing that it was spreading rapidly there, often driving out molasses grass (Uribe Uribe, 1955, p. 330-333). "If it doesn't deserve the title 'Queen of the grasses," " the General wrote with reference to Brazil, "it is only because of the incomparable Guinea grass." Cheese made in Minas Gerais from dairy cows fattened on jaraguá he pronounced the most exquisite he had ever eaten and he hoped that Colomibans might one day enjoy a comparable product. Once established in Colombia, he accurately predicted, it would be only a matter of time before it would take over the country, at least below the 1500-meter contour.

Colombia seems to have served as the staging base from which the red-tipped jaraguá, like molasses grass, spread to the rest of tropical Spanish America. It is in the decade of the 1920's that it is first reported in the Central Andes, in Central America and in the West Indies. Especially in the drier areas, where the dry season lasts five months or more, it has held a strong competitive advantage. Outside of Brazil, it has perhaps reached its maximum development in the drier western side of Central America, especially in Guanacaste and in Nicaragua where it is recognized as the base of a substantial livestock industry. It was surprisingly slow in reaching Mexico. It is first recorded for the Vera Cruz coast in 1924 and the following year was introduced into Tabasco where today it supports an important livestock industry around Palenque. Jaraguá is also prominent in Cuba where it was first sown on marginal 
lands in Oriente province as early as 1920. Six years later it was reported by Hitchcock as "becoming naturalized" near Camaguey. By 1950 , it was found throughout the island, "no pasture grass having ever spread so rapidly" (Alonso Olivé, 1953). In Puerto Rico, in contrast, it seems to have established itself much more slowly. In Venezuela, too its establishment must have initially have been slow. As late as 1936 Pittier could write that he had not yet encountered it there, although he suspected that it had been introduced (Pittier, 1937). Thirty years later it was one of the most widespread and conspicuous exotic grasses in that country.

Jaraguá's remarkable aggressivcness and its self-seeding ability is demonstrated by its capacity to compete with native savanna grasses. Clumps of jaraguá, well established and vigorously spreading, can be seen at the Llanos Experimental Station at Calabozo, Venezuela, far removed from any possible seed source and in the midst of a coarse Trachypogon savanna scattered with gnarled, fireresistant Curatella and Byrsonima trees. Within a generation, parts of the open Venezuelan Llanos may well be dominated by this aggressive African invader. Even more than the other exotic grasses in the New World tropics jaraguá appears to be aided by fire. After a number of years, it may tend to weaken and eventually be invaded by other species unless regularly burned. Stockmen, who know this well, fire jaraguá ranges each year in the dry season and graze it rather closely during the rainy period to avoid its becoming rank and fibrous, with progressively lower nutritive value.

\section{Kikuyu Grass}

In contrast to other African immigrants previously discussed, Kikuyu grass (Pennisetum clandestinum) belongs chiefly to the tierras frias. In the last twenty years, it has spread explosively throughout the higher elevations wherever there is no severe drought period. It shows very vigorous vegetative development of runners and stolons but its reproductive organs tend to be reduced and stunted. This concentration on vegetative matter probably enhances its value as pasture. In Ecuador and Colombia it prospers best above 6,000 feet coming down progressively lower as it moves away from the equator. In Mexico City, where it was introduced as a lawn grass perhaps as late as 1950 , it has invaded vacant lots as a weed and is a common grass in Chapultepec Park. But there it needs watering for good growth. In $\mathrm{La} \mathrm{Paz}$ it crowds out other lawn grass and grows aggressively in cracks in the pavement. It is a weed along the temperate coast of California, at least as far north as San Francisco Bay Area, where it is employed sparingly as a lawn grass. Originally from the slopes of Kilamanjaro and the Kenya-Uganda lake country, this mat-forming, stoloniferous species seems to have first reached the Americas in the early 1920's, probably through agricultural experiment station activity. The first references that $I$ have found to it are from 1923, and at three widely separated places-Brazil, Guatemala, and Peru. Characteristically, is has escaped from trial plots to overrun adjacent areas. At first considered an incradicable weed, it is today recognized as a valuable pasture grass in lower latitudes. In a period of about 40 years since its introduction onto the Sabana de Bogotá it has almost completely overrun every open field and roadside, choking out all competition. Similarly it has invaded the Quito basin and the upper yungas of Peru and Bolivia. It mantels the terraces of the famous ruins of Machu Picchu in Peru. On the slopes of Costa Rica's Irazú volcano, where it was introduced about 1928, it was long considered a pest which tended to dominate the so-called noble grasses such as orchard, rye and fescue in the zone from 6,000 to 9,000 feet. Following the 1964-65 eruptions of Irazú, when all other grasses were killed off, Kikuyu camc back carly and strong, apparently invigorated by the ash. Dairymen who once scorned it now describe Kikuyu as their strongest, most resistant and resilient pasture, supporting one head per acre throughout the year.

\section{Pangola Grass}

The most recent African invader is Pangola grass (Digitaria decumbens), apparently a very unimportant species in its home on the Pangola River in South Africa. It was introduced into a Florida experiment station in 1935 and from there was taken to the West Indies and the mainland of Central and South America. Like Kikuyu, it is propagated exclusively by stolons or stem cutting, being a sterile triploid that does not produce seed. Currently it enjoys great popularity in tropical America, although in some areas it is subject to a destructive virus disease. When healthy, its low, thick sward tends to crowd out all competition.

Pangola grass was introduced into Puerto Rico in 1946 and the same year into Costa Rica. For most other countries the date of its introduction is some time in the 'fifties. It has a wide range of adaptability and has been found doing well to elevations as high as 5,000 feet in Costa Rica and even higher in Colombia. In Jamaica it has been used extensively for rehabilitation of mined out bauxite areas. Its susceptibility to disease is currently resulting in its displacement on newly cleared lands in Mato Grosso, where it has enjoyed recent popularity, by an even newer African introduction, signal grass or Brachiara brizantha, also considered to have great promise.

There are other grasses, including several from the more temperate parts of the African continent, that are contributing to the "Africanization" of the tropical American grasslands. Among these are the ubiquitous Bermuda grass (Cynodon dactylon L.), Johnson grass (Sorghum halepensis L.), Rhodes grass (Chloris gayana 
Kunth), elephant grass (Pennisetum purpureum Schumach) and Natal grass (Tricholaena rosea Nees). Although some of these are aggressive colonizers, none has assumed the importance within the American tropics of the species reviewed.

This African invasion is reminiscent of the replacement of the California bunch grass by Mediterranean annuals, but in the tropical example human agency plays a larger role. The movement has been almost all one way, from Africa to the Americas, as is also the case with the Mediterranean grasses. The African grasses stand up bettcr to grazing and have higher nutritives values than native American species. In this respect the invasions can be considered advantageous, although botanists may mourn the disappearance of native members of the flora that it may cause. A somewhat similar, but less spectacular, spread of African grasses into the Southeast Asian tropics may also be documented (e.g. Burkhill, 1935; Bor, 1960; Whyte, 1968) but the secondary role of stock-raising there, together with the existence of aggressive, indigenous species such as Imperata cylindrica and Saccharum spontaneum, makes this invasion of a lesser order of consequence.

Good grazing grasses appear to develop under grazing pressure. Few cultivated grasses are indigenous to the New World. We have to go to the Great Plains, with its buffalo and grama grasses, to find anything remotely equivalent to the Old World grasses in terms of grazing value. From the American tropics come Bahia grass (Paspalum nolalum Fluegge), Carpet grass ( $A x$ onopus compressus Beauv.), and Imperial (Axonopus scoparius L.). But none of these are of major importance. It is instead the largely unnoticed but massive invasions of the vigorous African species that is at the base of the new hope for the development of a viable commercial livestock industry in the low latitudes of the New World tropics.

\section{Literature Cited}

Alonso Olivé, R. F. 1953. Pastos y forrajes, una vista panorámica de su historia en Cuba. Revista de Agricultura, Habana. 36:89-108.

ANon. 1922. Efwatakala grass-Melinis minutiflora, Beauv. Kew Bull. 10: 305-316.

Blydenstein, J. 1967. Tropical savanna vegetation of the llanos de Colombia. Ecology 48:1-15.

BoR, N. L. 1960. The grasses of Burma, Ceylon, India and Pakistan, excluding Bambuseae. Pergamon Press, Oxford, London, New York, Paris, 767 p.

Burkill, I. H. 1935. Dictionary of the economic plants of the Malay Peninsula. Crown Agents for colonies, London, 2 vols.

Chardón, C. 1930. Reconocimiento agro-pecuario del Valle del Cauca. Misión agrícola al Valle del Cauca, San Juan, Puerto Rico, 342 p.

Chase, A. 1944. Grasses of Brazil and Venezuela. Agr. in the Amer. 4: 123-126.

Chase, A., and G. Niles. (comps.), 1962. Index to grass species. G. K. Hall, Boston, 3 vols.

Cooper, J. P. 1965. The evolution of forage grasses and legumes. In: Sir Joseph Hutchinson, ed., Essays in crop plant evolution. Cambridge Univ. Press, Cambridge, 204 p. (p. 142-165)

EDWARDS, B. 1801. The history, civil and commercial, of the British colonies in the West Indies. J. Stockdale, London, 3 vols.

EsPonda, J. M. 1888. Manuel práctica del nuevo ganadero mexicana. Secretaría de Fomento, Mexico, 132 p.

García-Molinari, O. 1952. Grasslands and grasses of Puerto Rico. Univ. Puerto Rico, Agr. Exp. Sta. Bull. 102, Río Piedras, Puerto Rico, 167 p.

GardNER, G. 1846. Travels in the interior of Brazil. Reeve, London, $562 \mathrm{p}$.

Harris, D. R. 1965. Plants, animals and man in outer Leeward Islands. Univ. Calif. Publ. Geogr., 18, Univ. of Calif. Press, Berkeley and Los Angeles, $184 \mathrm{p}$.

HaRTley, W., AND R. J. Williams. 1956. Centres of distribution of cultivated pasture grasses and their significance for plant introduction. In: Proceedings, 7th Int. Grassland
Congr., Palmerston North. Wellington, N. Z., 611 p. (p. 190-200)

Hrtchсоск, A. S., AND A. Chase. 1917. Grasses of the West Indies. Contrib. U. S. National Herb. Vol. 18, pt. 7, p. 261-471. Government Printing Office, Washington.

Martinez, M. 1959. Plantas útiles de la flora mexicana. Ediciones Botas, Mexico, $621 \mathrm{p}$.

OfFicial CoRrespondence ReLATing to Para Grass. 1949. Royal Hortic. Soc., 4:44-49.

Ospina VÁsquez, L. 1955. Industria y protección en Columbia, 1810-1930. Editorial Santafe, Medellín, 531 p.

Parsons, J. J. 1968. Antioqueño colonization in western Colombia. Revised. Univ. of Calif. Press, Berkeley and Los Angeles, $233 \mathrm{p}$.

Pittier, H. 1937. Lista provisional de las Gramineas señaladas en Venezuela hasta 1936. Min. Agr. y Cria, Bóletin Técnica 1, Caracas, 77 p.

PitTieR, H. 1957. Ensayo sobre plantas usuales de Costa Rica. 2d. ed. Editorial Universitaria, San José, Costa Rica, 264 p.

Rattray, J. M. 1960. The grass cover of $\Lambda$ frica. FAO Agricultural Study No. 49, Rome, 168 p. with accompanying map.

Restrepo, J. M. 1952-1963. Historia de la Nucva Granada. Editorial Cromos, Bogotá, 2 vols.

Rivas, M. 1946. Los trabajadores de tierra caliente. Ministerio de Educación, Bogotá, 364 p.

Sroane, H. 1707-1725. A voyage to Madera ..... Printed by B. M. (British Museum) for the author, London, 2 vols.

Sternberg, H. O'R. 1968. Man and environmental change in South America. In: E. J. Fittkau et al. (eds.), Biogeography and ecology of South America. Dr. W. Junk, The Hague, 2 vols. (1:415-445)

Torres, A. Di P. 1954. Agressividade de algumas gramineas forrageiras na região de Piracicaba. Anais de Escola Superior de Agricultura (Luis de Queiroz) Brazil. 11:93-114.

Uribe Uribe, R. 1955. Por la América del Sur. Editorial Kelly, Bogotá, 2 vols.

Weintraub, F. 1953. Grasses introduced into the United States. U. S. Dep. Agr. Handbook 58. 79 p.

Whyte, R. O. 1968. Grasslands of the monsoon. Frederick A. Praeger, New York, Washington, $325 \mathrm{p}$. 